\title{
Hirschsprung's disease associated with Mowat-Wilson syndrome
}

\author{
Ramnik V Patel, ${ }^{1,2}$ Khalid Elmalik, $^{3}$ Nordine Bouhadiba, ${ }^{3}$ Rang Shawis ${ }^{3}$
}

${ }^{1}$ Department of Paediatric Urology, University College London Hospitals NHS Foundation Trust, London, UK ${ }^{2}$ Department of Paediatric Urology, Great Ormond Street Children Hospital NHS Trust, London, UK

${ }^{3}$ Department of Paediatric Surgery, Sheffiled Children's Hospital, Sheffiled, UK

Correspondence to Ramnik V Patel, ramnik@doctors.org.uk

Accepted 21 April 2014

CrossMark

To cite: Patel RV, Elmalik K, Bouhadiba $\mathrm{N}$, et al. BMJ Case Rep Published online: [please include Day Month Year] doi:10.1136/bcr-2013 203262

\section{DESCRIPTION}

A term male infant was born after an uneventful pregnancy and normal vaginal delivery with a birth weight of $3480 \mathrm{~g}$. There was no consanguinity among parents. He required no resuscitation at birth. He had typical dysmorphic facial features such as square-shaped face, a prominent but narrow triangular chin, deep set but large eyes, hypertelorism, saddle nose, broad nasal bridge, open mouth, everted lower lip, posteriorly rotated ears and large uplifted ear lobes with a central depression. Recognition of the characteristic facies led to referral for genetic counselling. He had delayed passage of meconium with abdominal distention and bilious vomiting on second day of life. He responded well to saline rectal washouts and rectal suction biopsy confirmed Hirschsprung's disease (figure 1). He was sent home with daily saline rectal washouts by parents until 3 months of age at which time he underwent primary Duhamel pull through operation using small hockey stick smiling left lower abdominal incision. His postoperative period was uneventful. Genetic team on investigation found it to be sporadic resulting from de novo deletion of the ZFHX1B gene with cytogenetic deletion of $2 q 22-23$. There was no indication of any deletion in the parental chromosomes on this identical location and therefore it was concluded that it was a de novo mutation rather than inherited pattern of the mendelian type. In addition he has glandular hypospadias, absent corpus callosum, abnormal EEG, moderate mental retardation and microcephaly. At 10-year follow-up he is progressing well, has normal bowel function and shows typical facial changes. Mowat-Wilson syndrome with Hirschsprung's disease is a complex syndromic genetic disease with multiple congenital anomalies and typical dysmorphic features with mental retardation. ${ }^{1}{ }^{2}$ Generally, the outcome of syndromic Hirschsprung's disease in such cases is very poor. ${ }^{3}$ Our case is exceptional and a strong reminder of the fact that we should at least give definitive surgery a chance to see how they do, and meticulously performed surgery does help.
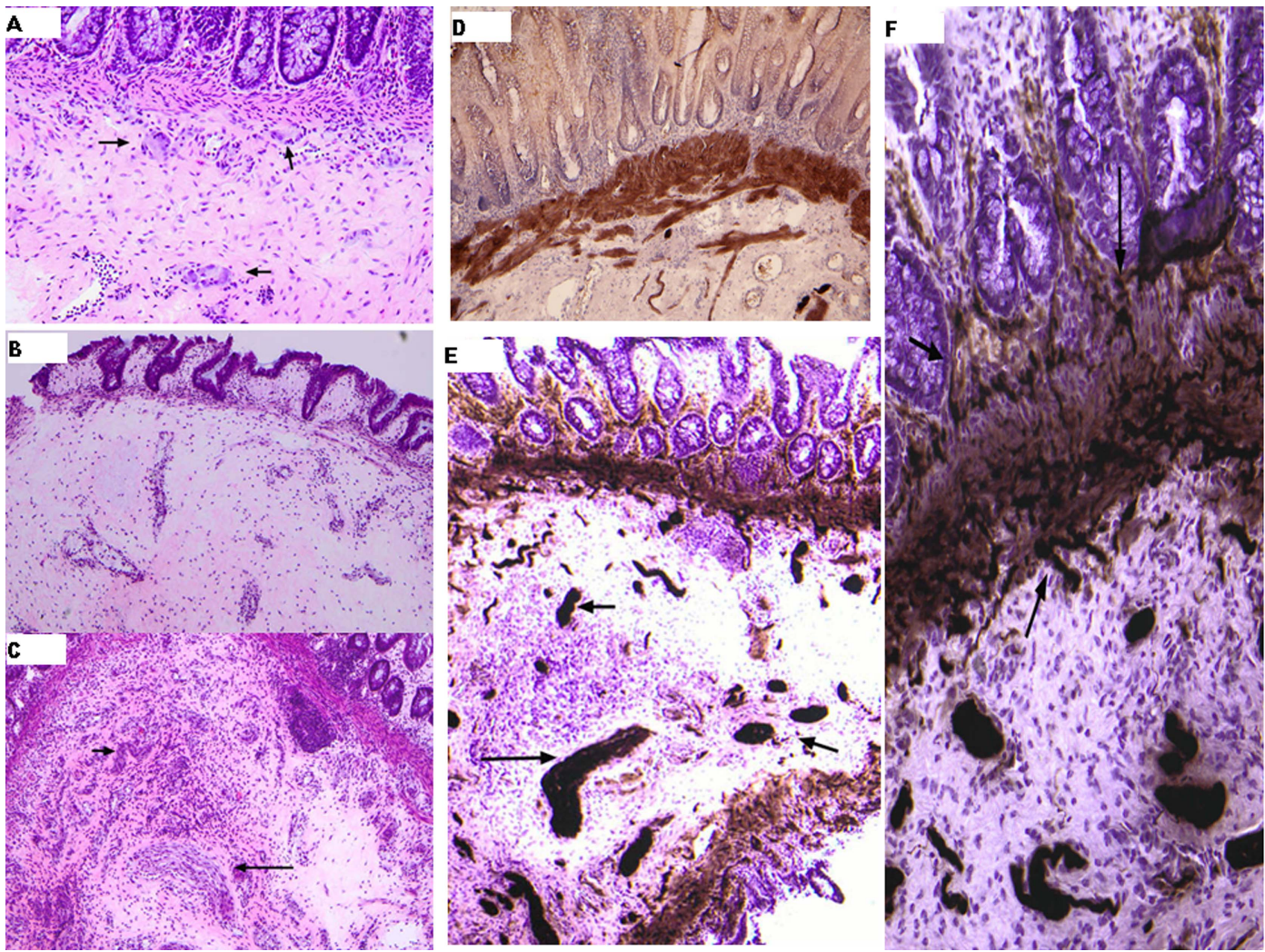

Figure 1 (A-C) Histology: $(A)$ normal control rectal biopsy showing several clusters of ganglion cells in the submucosa (arrows); (B) Patient's rectal biopsy showing no ganglion cells in the submucosa; (C) several large nerve trunks seen in the submucosa (arrows). (D and E) Acetyl cholinesterase histochemistry: (D) normal control Ache stain. There is only a light brown blush in the muscularis mucosa. There are no large nerves (these would stain black); (E) Ache stain showing the large nerves in (C) (arrows). (F) Ache stain showing abnormal nerves in the muscularis mucosa and lamina propria (arrows). 


\section{Learning points}

- Characteristic dysmorphic features in association with Hirschsprung's disease and multiple congenital anomalies and mental retardation should alert the possibility of Mowat-Wilson syndrome.

- Genetic counselling should be conducted and other conditions should be excluded. Normal parental genes and chromosomes may suggest a de novo mutation in the offspring.

- Generally speaking the outcome of pull-through operation for Hirschsprung's disease is very poor and our case is an exception to this rule perhaps due to de novo mutation and meticulously performed single stage neonatal primary pull-through surgery.
Contributors All the authors have made substantial contributions to the conception and design of this paper, search of literature, the acquisition, analysis and interpretation of the data, to drafting the article or revising it critically for important intellectual content and to the final approval of the version to be published.

Competing interests None.

Patient consent Obtained.

Provenance and peer review Not commissioned; externally peer reviewed.

\section{REFERENCES}

1 Leong M, Verey F, Newbury-Ecob R, et al. Supernumerary intestinal muscle coat in a patient with Hirschsprung's disease/Mowat-Wilson syndrome. Pediatr Dev Pathol 2010:13:415-18.

2 Cuturilo G, Stefanović I, Jovanović I, et al. Mowat-Wilson syndrome-a case report. Srp Arh Celok Lek 2009;137:426-9.

3 Bonnard A, Zeidan S, Degas V, et al. Outcomes of Hirschsprung's disease associated with Mowat-Wilson syndrome. J Pediatr Surg 2009:44:587-91.

Copyright 2014 BMJ Publishing Group. All rights reserved. For permission to reuse any of this content visit http://group.bmj.com/group/rights-licensing/permissions.

BMJ Case Report Fellows may re-use this article for personal use and teaching without any further permission.

Become a Fellow of BMJ Case Reports today and you can:

- Submit as many cases as you like

- Enjoy fast sympathetic peer review and rapid publication of accepted articles

- Access all the published articles

- Re-use any of the published material for personal use and teaching without further permission

For information on Institutional Fellowships contact consortiasales@bmjgroup.com

Visit casereports.bmj.com for more articles like this and to become a Fellow 